\author{
ARTIGOS \\ TERRITÓRIO, CIDADANIA E DIREITOS
}

\title{
ENTREVISTAS NA PESQUISA SÓCIO-ESPACIAL
}

Silke Kapp* * Escola de Arquitetura, Departamento de Projetos, Universidade Federal de Minas Gerais (UFMG) Belo
Horizonte, Minas Gerais, Brasil.

\section{Resumo}

A coleta de dados por meio de entrevistas tem sido uma prática corrente nas pesquisas em arquitetura, urbanismo e planejamento, enquanto ainda são raras as discussões metodológicas sobre a pertinência, os objetivos, as formas de condução e as especificidades de entrevistas qualitativas nessas disciplinas. Este artigo visa a elucidar por que e como entrevistas qualitativas podem prover ou gerar dados sócio-espaciais cujas análise e interpretação, por sua vez, podem levar a conhecimento válido. Ele começa examinando as funções atribuídas a dados de entrevistas e seus limites. Em seguida, são evidenciadas diferentes ênfases de entrevistas partindo de cinco tipos consolidados em outras áreas (entrevista exploratória, etnográfica, narrativa, focada e especialista). A intenção não é propor escolhas entre eles nem criar mais um tipo, mas abrir um leque de variações a combinar, detalhar e expandir, de acordo com a situação específica de cada pesquisa.

Palavras-chave

Entrevistas; Metodologia; Pesquisa sócio-espacial; Pesquisa qualitativa; Narrativa. 


\title{
ARTICLES
}

TERRITORY, CITIZENSHIP AND RIGHTS

\section{INTERVIEWS IN SOCIO-SPATIAL RESEARCH}

\author{
Silke Kapp* \\ * Escola de Arquitetura, Departamento de Projetos, Universidade Federal de Minas Gerais (UFMG) Belo \\ Horizonte, Minas Gerais, Brasil
}

\begin{abstract}
Data collection through interviews has been a current research practice in architecture, urban design and planning, while the methodological discussions on the relevance, objectives, conduction and specificities of interviews in these disciplines are still rare. This paper aims at elucidating why and how qualitative interviews can provide or generate socio-spatial data whose analysis and interpretation may lead to valid knowledge. It begins by examining the roles assigned to interview data, and their limits. Then it highlights various interview emphases drawing on five types, consolidated in other areas (exploratory, ethnographic, narrative, focused, and expert interview). The intention is not to propose choices between them nor to create another type, but to open a range of variations that may be combined, elaborated and expanded according to the situation of each research.
\end{abstract}

Keywords

Interviewing; Methodology; Socio-spatial research; Qualitative research; Narratives. 


\section{ENTREVISTAS NA PESQUISA SÓCIO-ESPACIAL}

Silke Kapp

\section{Por que discutir entrevistas}

Como em muitas áreas do conhecimento, a coleta de dados por meio de entrevistas tem sido uma prática corrente nas pesquisas em arquitetura, urbanismo e planejamento. No entanto, ainda são raras as discussões sobre a pertinência, os objetivos e as formas de condução, avaliação e interpretação de entrevistas nessa área. Salvo engano, não foram objetos de publicações específicas e, para além do adjetivo ‘semiestruturada' e de eventuais menções a registro, transcrição e análise, pesquisadoras e pesquisadores pouco têm explicitado como e por que utilizam entrevistas. Sem dúvida, apoiam-se em métodos que outras ciências sociais e humanas discutem há tempos. Mas existem peculiaridades que merecem uma reflexão específica, ao menos em se tratando de pesquisas sócio-espaciais, isto é, aquelas que abordam sociedade, espaço e suas relações. ${ }^{1}$

Uma dessas peculiaridades é a dificuldade de comunicação em temas concernentes ao espaço. Imagens, noções e símbolos com que o espaço é tratado cotidianamente não correspondem ao jargão e às representações objetivadas do campo especializado, que não apenas são estranhos à maioria das pessoas, como provêm de uma tradição de planejamento e controle pouco interessada em experiências e processos de produção espaciais de 'leigos'. Outra peculiaridade das pesquisas sócio-espaciais em planejamento, urbanismo e arquitetura é que costumam envolver proposições, com perguntas que, além de confundirem as

1. Como Souza (2013), mantenho a grafia sócio-espacial, com hífen, por entender que tais relações são também conflituosas e antagônicas, não formando o continuum que a grafia socioespacial sugere. 
“declarações de intenção com as probabilidades de ação” (BOURDIEU et al., 2007, p. 51), exigem da pessoa entrevistada uma prospecção concreta num futuro fictício, talvez envolvendo mudanças substanciais na sua situação pessoal e social. Pergunte-se, por exemplo, a uma moradora de periferia se ela se mudaria para o centro da cidade se ali houvesse um programa habitacional acessível. A pergunta pressupõe que a opinião sobre uma questão complexa como essa exista prévia e isoladamente, como se não precisasse de tempo para amadurecer nem se orientasse por outras opiniões. A mesma pergunta feita, digamos, a uma assembleia de luta por moradia talvez provocasse debates e transformasse as opiniões individuais anteriores. De todo modo, entrevistas não seriam um fundamento confiável para justificar a adoção ou a desistência daquele programa habitacional no centro da cidade. Apenas isso basta para considerar que métodos e técnicas de entrevista provenientes de outros campos não esgotam a questão da entrevista em áreas como planejamento, arquitetura e urbanismo.

O presente texto é uma tentativa de avançar nessa discussão, elucidando especificidades das entrevistas qualitativas e sua pertinência para pesquisas sócio-espaciais. O estudo que lhe deu origem foi motivado, justamente, pela relativa escassez de discussões metodológicas sobre o tema na área de arquitetura, urbanismo e planejamento, procurando trazer para ela, mediante a recuperação de debates de outras áreas, algumas questões fundamentais acerca dessa forma de coleta e construção de dados.

Começo por abordar as funções atribuídas a dados de entrevistas. Depois procuro evidenciar diferentes ênfases de entrevistas partindo de tipos relativamente consolidados (exploratória, etnográfica, narrativa, focada, especialista). A intenção não é criar mais um tipo nem propor uma tipologia de elementos fechados e estanques, entre os quais seria preciso escolher, mas abrir um leque de variações que podem ser consideradas, elaboradas e recombinadas em cada caso e que podem inspirar novas formas de abordagem. A reflexão é metodológica no sentido estrito do termo: tem o intuito de elucidar a lógica dos métodos ou elucidar por que levariam a dados que, por sua vez, podem subsidiar conhecimento com pretensão de validade. A discussão se baseia na literatura das ciências sociais sobre o tema - aliás, tão vasta que sua revisão sistemática exigiria mais do que um artigo - e em experiências de pesquisas realizadas e debatidas ao longo dos últimos quinze anos com colegas do Grupo de Pesquisa MOM (Morar de Outras Maneiras) e de outras instituições, regiões e países. 


\section{Perguntas de pesquisa e perguntas de entrevista}

A estrutura de uma investigação científica, incluindo as decisões sobre se, como e com quem realizar entrevistas, depende da chamada pergunta de pesquisa. Mais do que satisfazer uma curiosidade ou uma demanda particular de informação, sua resposta deve acrescentar algo ao conhecimento compartilhado num campo. Ela indica uma lacuna que se quer preencher. Em disciplinas como a sociologia, mas também nas chamadas ciências duras, prevalece o entendimento de que "a base de conhecimento compartilhada existe na forma de teorias", de modo que "uma pergunta de pesquisa deve descrever uma lacuna teórica" (GLÄSER; LAUDEL, 2009, p. 64). Se a pesquisa for bem-sucedida, capaz de responder à pergunta, ela afetará uma teoria existente, ampliando-a ou a refutando.

Esse princípio cabe às pesquisas em arquitetura, urbanismo e planejamento? Trata-se de um campo sem um corpo teórico imperativo e com uma forte tradição de pesquisa prático-profissional, que inclui o levantamento de dados para projetos e planos sem a pretensão de produzir conhecimento mais abrangente do que o aplicável àquele caso singular (diagnósticos e programas de necessidades, por exemplo). Não que essa prática seja em si um problema - pelo contrário, nada é pior do que planos que ignoram a singularidade de uma situação e se baseiam apenas em teorias e preconcepções. O problema é que mesmo um levantamento empírico sem ambição teórica fará uso de alguma teoria ou prototeoria acerca de seu objeto. Vemos o que estamos dispostos a ver. A escolha não se dá entre reunir dados com ou sem preconcepções, e sim entre reuni-los com ou sem (relativa) consciência delas. Ainda o intuito de apenas descrever uma situação sócio-espacial, se for levado a cabo com a consciência de que toda descrição é seletiva, não escapará do discernimento dos critérios de seleção, que sempre provêm de alguma teoria. $\mathrm{O}$ esforço de trazê-los à tona, justamente para ir além das preconcepções, impõe uma atitude de vigilância sistemática aos sinais de sua inadequação. Apenas a reflexão do trabalho empírico - que é teórica - permite corrigir rumos e ir além do que já foi constatado centenas de vezes em centenas de lugares.

Portanto, se entendermos o termo teoria num sentido razoavelmente amplo, admitindo que possa abranger também o chamado senso comum culto (as prototeorias), o princípio acima enunciado vale, sim, para o campo da arquitetura, do urbanismo e do planejamento: uma pergunta de pesquisa designa uma lacuna teórica e a resposta afeta a teoria em questão. E esse princípio vale mesmo para estudos exploratórios ou em situações em que a pergunta, no início, é pouco mais do que uma desconfiança. Nada impede que ela seja ajustada, especificada e reformulada no percurso. 
Se uma lacuna teórica estrutura uma pesquisa, preenchê-la exige criar caminhos que levem a dados relevantes. Entrevistas são caminhos dessa espécie, isto é, métodos para obter ou produzir dados. Elas não são, por si mesmas, respostas à pergunta de pesquisa. Só farão sentido se forem precedidas de uma preparação crítica, e analisadas e interpretadas em conjunto com outros dados e com (ou contra) as teorias. Bourdieu, Chamboredon e Passeron (2007, p. 50) dizem que a "maldição das ciências humanas talvez seja o fato de abordarem um objeto que fala”, porque os pesquisadores ficam tentados a tomar as explicações das pessoas acerca de suas condutas pelas explicações dos processos (sociais) investigados.

Para ilustrar a diferença entre respostas a uma pergunta de pesquisa e respostas de entrevistas (aliás, dados empíricos em geral), veja-se a crítica de Paul Singer aos estudos das migrações campo-cidade no Brasil. Singer (2002, p. 52) adverte que muitos deles tomam como causas de um processo social e coletivo "as verbalizações dos migrantes quanto aos motivos que os teriam levado a migrar”, resultando em "análises psicologizantes, em que as principais condicionantes macrossociais são desfiguradas quando não omitidas”. Migrantes podem compartilhar experiências subjetivas e podem fornecer dados objetivos específicos (quanto tempo durou a seca, quem ficou doente, que serviços existiam na região), mas é improvável que mencionem como motivos de sua migração os arranjos institucionais de uma industrialização capitalista periférica, a implantação tecnológica do agronegócio ou coisas semelhantes. Por outro lado, entrevistas com migrantes podem esclarecer como processos macrossociais e macroespaciais se manifestam concretamente em diferentes contextos, que formas de resistência surgem ali e o que as alimenta ou desmantela. Uma pesquisa feita para decifrar os obstáculos que uma política de agricultura familiar precisaria remover (além da óbvia falta de acesso à terra) talvez tirasse tanto proveito de entrevistas com migrantes quanto de entrevistas com camponeses remanescentes. Portanto, a função e a pertinência dos dados obtidos em entrevistas variam com a pergunta de pesquisa.

Penso que uma razão da popularidade e do uso por vezes leviano de entrevistas é que a escolha por elas frequentemente decorre da facilidade operacional, não de uma decisão metodológica. Soa banal, mas a ascensão das técnicas de entrevista aberta coincide com a ascensão do gravador portátil. Ele permite que ainda o pior entrevistador obtenha grande volume de dados na forma de textos, porque as pessoas têm "quase sempre suficiente boa vontade para responder, no mínimo, qualquer coisa a qualquer pergunta” (BOURDIEU et al., 2007, p. 56). Como monografias, dissertações e teses também são constituídas de textos, surge a sedutora ilusão de que transcrições ou paráfrases de entrevistas, com eventuais comentários, bastam para cumprir os requisitos de tal trabalho acadêmico. Mas, se isso 
fosse verdade, ou a pesquisa teria sido desnecessária porque a resposta à pergunta de pesquisa já seria de domínio comum, ou então o título a que o entrevistador aspira caberia ao entrevistado.

\section{Argumentos contra e a favor das entrevistas}

Na década de 1960, quando entrevistas e questionários eram quase sinônimos de pesquisa social empírica, a enquete individual por amostragem probabilística foi duramente criticada por Allen Barton (1968, p. 1) como "um triturador sociológico, arrancando o indivíduo do seu contexto social [...] como um biólogo que põe seus animais de laboratório numa máquina de hambúrguer e examina uma a cada cem células sob o microscópio”. Barton dizia que o mais importante para a pesquisa social - interações, papéis, comunicação, poder - era deixado de fora da coleta de dados de base individual. Contra isso, ele reclamava a volta da sociedade para o interior das pesquisas - "bringing society back in", como se vê no título de seu artigo - mediante a amostragem por clusters e a investigação focada nas relações entre os indivíduos. Métodos como o snowball sampling (GOODMAN, 1961) e as entrevistas em grupos também surgiram para tentar superar essa atomização da entrevista individual.

Na mesma época, Bourdieu tentava "restituir à observação metódica e sistemática seu primado epistemológico", argumentando que toda entrevista cria uma situação social artificial, que "rompe a reciprocidade das trocas costumeiras" e "incita os sujeitos a produzir um artefato verbal" (BOURDIEU et al., 2007, p. 55 e p. 58). As pessoas dizem o que lhes parece adequado, não na vida, mas na circunstância da entrevista, com todas as assimetrias que ela implica. Ações reais podem ser ignoradas se o levantamento de dados se limitar a entrevistas, pois, no melhor dos casos, elas registram "resultado da observação efetuada pelo sujeito sobre suas próprias condutas”, não as condutas enquanto tais (idem, p. 59).

Um exemplo de observação sem entrevistas é o seminário "Sobre a sociologia do riso" oferecido por Theodor W. Adorno no Instituto de Pesquisa Social em Frankfurt, em 1964 - um experimento heterodoxo que deveria introduzir os estudantes à pesquisa social empírica e exercitar sua imaginação sociológica (SCHÖRLE, 2003). Houve uma breve discussão sobre o riso enquanto fenômeno social e então os estudantes foram a campo. O trabalho consistia na observação de situações cotidianas - na rua, no ônibus, em reuniões etc. - em que pessoas riam, individual ou coletivamente. Faziam-se anotações precisas de cada situação (ocasião, motivação, tipo do riso, participantes, quem riu sem ser do grupo, quem não riu etc.) seguidas de interpretações. O material foi tão rico que os encontros semanais já não bastavam para discutir os achados. Resultou do seminário o esboço de uma tipologia do riso 
que nenhum formato de entrevista proveria. Pelos critérios de cientificidade mais instituídos, dizia-se que o problema de tal observação direta seria a impossibilidade de reproduzir as situações observadas e questionar as interpretações, à diferença da entrevista gravada e transcrita, que gera um indício aparentemente verificável. Resta saber se a prova de que alguém de fato disse aquilo assegura objetividade a uma pesquisa - a mim parece que não.

Por outro lado, há de se considerar que as críticas acima provêm de um período em que, na metáfora de Kvale (1996), predominava o entendimento do entrevistador como um minerador, que primeiro traz à tona um material enterrado e depois o limpa e purifica mediante análises ditas científicas. Parte dessas críticas deixa de valer quando, em vez disso, o entrevistador entende a si mesmo como um viajante que experiencia terreno novo conversando com outras pessoas e descobrindo vistas inesperadas. Aliás, conversar une o prefixo latino con- e o verbo versare, virar, mudar de rumo. Conversar significa mudar de rumo junto com alguém (a origem é a mesma de converter). O entrevistador não é neutro nesse processo nem precisa fingir ausência de envolvimento pessoal (LILLRANK, 2012).

Mas há outras críticas relevantes. Atkinson e Silverman (1997, p. 304) questionaram a "fé na entrevista como o principal meio de coleta de dados" por parte de antropólogos e sociólogos, porque viram nela a reprodução ingênua dos mitos da "sociedade da entrevista" com sua "celebração neorromântica do sujeito falante”. De fato, entrevistas haviam se tornado onipresentes nos anos 1990, como são ainda hoje - em talk shows, noticiários, revelações de artistas, desportistas e outras celebridades. Nesse contexto, a subjetividade que fala, se abre, confessa, tornou-se fonte supostamente segura e autêntica também para as ciências sociais. "As técnicas dos mass media contemporâneos e os interesses da pesquisa social convergem nas formas culturais da sociedade da entrevista” (Idem, 1997, p. 309). O risco é que, "ao concentrar-se em vozes falantes e eus narrativos, a pesquisa sociológica e antropológica fundamente a si mesma nas tecnologias da sociedade da entrevista em vez de questionar sistematicamente seus pressupostos e métodos básicos” (Idem, 1997, p. 322).

Portanto, os argumentos contra as entrevistas são muitos: atomização; artificialidade da situação; distância entre pensar, dizer e agir; adesão acrítica à encenação de personagens. Considerando-se que temas relacionados ao espaço implicam dificuldades adicionais, é recomendável indagar se de fato as entrevistas serão uma boa maneira de chegar aos dados pretendidos, em que medida elas devem ser complementadas por outras formas de coleta de dados ou se, por sua vez, serão apenas um complemento. 
Ainda assim, entrevistas são oportunidades de uma interação com pessoas e mundos que não existiria por outros meios. Esse é o argumento principal e suficiente a seu favor. Importa observar suas limitações, acirrar a vigilância ética e epistemológica, e ter alguma clareza sobre o que se procura, quem são os potenciais entrevistados, como abordá-los e o que suas expressões significam no processo de pesquisa. A maneira de preparar, realizar e avaliar entrevistas depende da concepção continuamente refletida desse processo, não da adesão a um método ou uma técnica consagrados.

\section{Variações e interfaces das entrevistas qualitativas}

A distinção mais elementar entre tipos de entrevistas decorre do formato das perguntas e da condução que ele implica. Uma modalidade é a entrevista fechada, estruturada ou diretiva, também chamada de questionário, que em princípio não pertence aos métodos qualitativos. As pessoas entrevistadas - em grande número - devem fornecer respostas breves e diretas a perguntas precisas, que lhes são apresentadas sempre da mesma forma e na mesma ordem. As respostas correspondem a opções dadas (múltipla escolha) ou são codificadas como tais pelo entrevistador. As análises se fazem por métodos estatísticos.

O extremo oposto seria a entrevista aberta, não estruturada ou não diretiva, em que a pessoa entrevistada é estimulada a se expressar, determinar temas, contar sua história e sua perspectiva das coisas, muitas vezes a partir de uma proposta inicial de fala ou 'pergunta grand tour'. Nesse caso o número de entrevistas é reduzido, e cada uma delas configura uma unidade de análise de direito próprio, interpretada conforme o contexto teórico da pesquisa (análise casuística, hermenêutica, biográfica, de discurso etc.; cf. SCHNEIDER et al., 2006).

Entre os extremos estaria a chamada entrevista semiestruturada. Em rigor, trata-se de uma técnica em que as questões são predeterminadas, como no questionário, e as respostas são livres, como na entrevista aberta. Uma vez que as perguntas devem seguir sempre a mesma ordem, sem comentários ou desvios por parte do entrevistador, o levantamento abrangente das variações de respostas, por essa técnica, exige realizar um número razoável de entrevistas (pelo menos trinta, dizem Mcintosh e Morse [2015]). A análise opera então por comparação, item a item, das (trinta) respostas obtidas a cada pergunta. Contudo, muitos autores têm usado o adjetivo ‘semiestruturado' para quaisquer procedimentos que geram respostas discursivas a certo campo temático - definido pelo entrevistador -, mas evitam aquela ruptura total com a interação social normal (leia-se, conforme às normas sociais de cada circunstância) que a atitude interrogativa do questionário 
e a ostensiva não intervenção da entrevista aberta mais tradicional impõem. Na realidade, quase todas as entrevistas ditas semiestruturadas (semi-structured interview) caberiam melhor na categoria geral da entrevista guiada (guided interview):

A entrevista guiada reflete a estrutura do campo de pesquisa e lista as perguntas que serão feitas a cada participante. Ela não concentra as respostas dos participantes em nenhum aspecto particular de suas experiências e frequentemente começa com uma pergunta 'grand tour'. Então, dependendo das respostas do participante, o pesquisador segue adiante com uma lista vagamente organizada de questões. Nem as repostas são coletadas item a item, nem a análise prossegue item a item, mas antes por temas ou categorização. (MCINTOSH; MORSE, 2015, p. 2.)

Já em se tratando de distinções mais minuciosas do que essas - entre questionário, entrevista guiada e entrevista aberta -, a literatura sobre entrevistas de pesquisas (research interviews) produziu uma verdadeira inflação taxonômica. Cada área, tradição ou autor parece querer assegurar suas definições e tipificar seus procedimentos com base no respectivo marco teórico. Esse furor de legitimação e padronização decorre da "vontade de imitar os sinais exteriores mais reconhecidos do rigor das disciplinas científicas” (BOURDIEU, 2003, p. 693), mas também da cada vez mais corriqueira terceirização do trabalho de campo, envolvendo pesquisadores iniciantes e prestadores de serviço externos.

Em vez um resumir um elenco de tipos derivados dessas diferentes tradições e de seus expedientes operacionais, minha intenção aqui é esclarecer variações ou ênfases de alguns deles, que me parecem de maior interesse para as entrevistas no contexto de pesquisas sócio-espaciais. Não se trata, como já dito, de inventar um tipo pretensamente novo (algo como $A$ entrevista sócio-espacial), nem de eleger técnicas ou métodos privilegiados, mas de evidenciar aspectos que podem ser combinados segundo a metodologia - a reflexão sobre os métodos - de cada projeto de pesquisa. São eles:

- O caráter exploratório, que indica a realização no início (de uma etapa) da pesquisa.

- O caráter etnográfico, que indica a inserção num contexto sócio-espacial concreto.

- O caráter narrativo, que indica o estímulo à 'contação de casos'.

- O caráter focado, que indica a concentração num tema específico.

- O caráter especializado, que indica a influência do interlocutor num campo de ação.

As ênfases acima não se excluem mutuamente, ainda que algumas conjunções sejam improváveis. A maneira de combiná-las e aproveitá-las depende dos dados que se pretende colher ou gerar, das pessoas entrevistadas e de suas 
respectivas circunstâncias. No entanto, todas as ênfases e combinações têm dois aspectos em comum. O primeiro é que serão aqui consideradas no contexto de pesquisas sócio-espaciais, não psicoespaciais: as pessoas entrevistadas são sujeitos e falam a partir de sua subjetividade, a ser respeitada e reconhecida, mas, ainda assim, pesquisas sócio-espaciais pretendem elucidar condições objetivas, relações entre pessoas, grupos, espaços, estruturas e agências, não o psiquismo individual. O segundo aspecto comum a todas as variações é que os dados gerados serão qualitativos, não quantitativos ou quantificáveis. Podem evidenciar algo que não seria descoberto de outro modo, mas cuja relevância para a totalidade daquele universo permanece sempre hipotética. A plausibilidade das hipóteses está relacionada à sua potência explicativa, não à confirmação por certo número de entrevistas.

Em contrapartida, obter dados que abrangem um universo social ou espacial na sua totalidade exige a seleção de uma amostra estratificada de entrevistados ou - se aquele universo não for suficientemente conhecido para se definir a representatividade de uma amostra - entrevistas em (quase) todas as suas instâncias: todas as pessoas de um grupo sócio-espacial, todas as famílias de uma ocupação urbana, todas as prefeituras de uma região metropolitana etc. Para pesquisas que têm por objeto espaços marginalizados, informais ou em processo de rápida transformação, e dependendo do que se quer descobrir, pode ser imprescindível realizar minicensos mediante questionários. Eles não são temas do presente texto, contudo vale notar que requerem um trabalho preparatório cuidadoso, que inclui entrevistas qualitativas para delinear temas e linguagens relevantes no respectivo universo, assim como vieses e induções a tentar evitar. Caso contrário, corre-se o risco de um imenso esforço operacional para a obtenção de dados que nada acrescentam. Um questionário elaborado para um contexto sócio-espacial e aplicado sem mais a outro contexto gera informações que parecem úteis porque se deixam comparar facilmente, mas é bem possível que passe ao largo de tudo o que realmente importa naquele (segundo) contexto.

Antes de discutir cada uma das ênfases, cabe uma observação sobre o chamado roteiro de entrevista. Por vezes ele é entendido como uma simples lista de temas pelos quais se gostaria que a conversa passasse, outras vezes como aquele conjunto estrito de perguntas das entrevistas de fato semiestruturadas (não apenas guiadas). Ora, é evidente que qualquer entrevista de pesquisa pressupõe alguma preparação. Mas pensar sobre os temas e saber a que prestar atenção ainda não constitui um roteiro. Roteiro, para efeito do presente texto, é uma agenda que não está apenas na cabeça de quem propõe a entrevista, mas cuja existência a pessoa entrevistada percebe claramente, ainda que não conheça seu conteúdo: um papel que ela vê a entrevistadora consultar, uma lista de tópicos a acompanhar, um elen- 
co de fotografias a comentar uma por uma, um trajeto de caminhada definido pela entrevistadora etc. A consciência da existência desses artifícios significa a consciência de que as rédeas estão com a entrevistadora e, para o bem ou para o mal, marca a diferença entre a entrevista e uma conversa espontânea. Já aquilo que nas pesquisas do Grupo MOM chamamos de interfaces abrange também os dispositivos usados para apoiar ou estimular entrevistas, tendo ou não a função de roteiro. Fotografias oferecidas como inspiração, não como programa, seriam interfaces sem se caracterizarem como roteiros.

A interface básica nesse sentido é o próprio local ou percurso onde se faz a entrevista - um tema pouco considerado na literatura, mas crucial para entrevistas sócio-espaciais. Como argumenta Hannah Herzog (2012, p. 212), do arranjo logístico de uma entrevista depende sua construção como um evento social entre parceiros, geralmente, desiguais: “A entrevista, quase por definição, recontextualiza relações sociais. A locação física em que a entrevista é conduzida é uma das mais concretas expressões desse processo de cruzamento de fronteiras”. Os manuais de técnicas de entrevistas costumam recomendar que a pessoa entrevistada escolha o lugar para que se sinta à vontade. Há de se ter em conta, entretanto, que o universo das escolhas à disposição de alguém também reflete desigualdades. Para privilegiados, ela tende a reforçar o status, enquanto para desprivilegiados vale o oposto. Ser convidado a conduzir uma entrevista na casa ou no local de trabalho de alguém significa uma licença para entrar num universo social a que não se teria acesso sem mais. A questão é se essa pessoa poderia sugerir, por exemplo, que a entrevista acontecesse na casa ou no local de trabalho da entrevistadora (o que seria um cruzamento de fronteiras em sentido oposto). De qualquer modo, uma prática da etnografia importante para pesquisas sócio-espaciais, mas que costuma ser negligenciada, é o relato detalhado do lugar da entrevista, de como ele foi negociado e da situação em que a conversa aconteceu (BEAUD; WEBER, 2014). Quem o definiu? Que opções havia? Como era o lugar? Como chegaram lá? O que estava acontecendo por perto? Que conteúdos foram motivados por esses elementos?

Um tema que, pela sua relevância para as pesquisas sócio-espaciais, merece uma discussão à parte - maior do que permitiria o presente artigo - é a condução de entrevistas em situações de atividade e itinerância: uma caminhada pela vizinhança, uma manifestação pública, um trabalho conjunto, uma viagem de ônibus, uma imersão em ambiente digital etc. Conversar enquanto se percorre um espaço facilita, subjetiva e objetivamente, a comunicação a respeito dele (cf. THIBAUD, 2001; BÜSCHER et al., 2010; EVANS; JONES, 2011). 


\section{Explorações}

Entrevistas de caráter exploratório servem como ponto de partida para conhecer um contexto de que o pesquisador ainda sabe pouco, geralmente num momento em que também a pergunta de pesquisa está relativamente imprecisa. Dado que isso vale para pesquisas muito diversas, a entrevista exploratória, como um tipo de direito próprio, aparece pouco na literatura, embora muitos autores a mencionem como estágio preliminar. Sobre as entrevistas exploratórias em pesquisas etnográficas, Beaud e Weber (2014, p. 124) dizem: “Tateará o campo. Aprenderá a situar-se no meio pesquisado. Lançará balões de ensaio. Identificará os traços pertinentes de uma questão”. A prioridade é abrir novas frentes.

Entrevistas de caráter exploratório, tais como entendidas aqui, visam à obtenção de informações de que as pessoas entrevistadas em geral já dispõem, à diferença de visões ou percepções construídas durante a própria entrevista. A tentativa é de que digam o que consideram importante a respeito de uma situação, um processo, um espaço. Perguntas elaboradas de antemão são pouco favoráveis a isso, porque impõem aos entrevistados uma categorização do mundo, "uma estruturação dos problemas que não é a sua", levando a "respostas que chamamos reativas”, como diz Thiollent (1980, p. 48). O equívoco não está na existência de uma "problemática de investigação" (a pergunta de pesquisa), e sim na "ausência de relativismo cultural por parte dos investigadores, cuja imaginação sociológica não ultrapassa o universo mental de seu próprio meio social” (THIOLLENT, 1980, pp. 51-52). Outros autores distinguem entre questões exmanentes, formuladas segundo o interesse e a linguagem do pesquisador, e questões imanentes, postas pelos sujeitos pesquisados segundo sua linguagem e visão de mundo (BAUER, 1996). Considerando isso, o que perguntar numa entrevista de caráter exploratório sem constranger os interlocutores a respostas artificiais?

[...] [deixe] claro a seus interlocutores que acabou de 'estar iniciando a pesquisa'. Peça-lhes que o ajudem nesse empreendimento. ('Apenas estou dando os primeiros passos', 'Vou fazer-lhes algumas perguntas um pouco ingênuas' etc.) Faça mais que o possível para precisar os fatos que lhe contam (nome de lugar, de pessoa, de empresa, de associação...); seus interlocutores terão prazer em explicar-lhe o que você não conhece ou compreende mal; encoraje-os [...] a colocar-se na função de quem lhe ensina alguma coisa. (BEAUD; WEBER, 2014, p. 124.)

A recomendação de "precisar os fatos que lhe contam" é importante, porque entrevistas de caráter exploratório buscam especificidades. Se delas resultarem apenas lugares-comuns e frases feitas, a pesquisa não avançará. Esse equilíbrio 
entre abertura das perguntas e precisão das respostas talvez seja o aspecto mais difícil das entrevistas cuja ênfase está na exploração inicial de um campo, objeto ou grupo. Por isso, convém refletir antes sobre as possibilidades de descoberta e preparar um fio condutor, mas não um roteiro no sentido acima indicado. As melhores perguntas decorrerão da própria conversa, que tende a se desenvolver como diálogo informal. A pessoa que entrevista ouve mais do que fala, porém ainda assim interrompe, pede detalhes, verifica, expande temas de interesse.

Outra dificuldade nas entrevistas de caráter exploratório é a seleção de entrevistados, na maioria dos casos aleatória (o dono do bar da esquina) ou definida pelo grupo (a secretária, a liderança, o porta-voz). Há grupos que indicam agentes externos (a técnica da prefeitura, o advogado do movimento) para se livrar da situação ou porque supõem que esses agentes teriam maior competência para informar o que o pesquisador quer saber. Dado que nas entrevistas iniciais de uma pesquisa tem-se pouca noção da inserção dos interlocutores no respectivo contexto e da influência que suas opiniões exercem ali, convém ampliar o círculo, tentar falar com mais pessoas. De todo modo, não cabe sobrevalorizar as entrevistas iniciais com análises minuciosas, pois dirão mais sobre a ignorância dos pesquisadores do que sobre o objeto estudado ou as nuances da visão dos entrevistados (JOHNSON; ROWLANDS, 2012). Pela mesma razão, entrevistas iniciais dificilmente serão aprofundadas, ainda que, assim como as entrevistas em profundidade, sejam de condução aberta e perguntas espontâneas.

Para pesquisas que dizem respeito a um contexto espacial particular (microbacia, bairro, vila, ocupação, quilombo etc.), a exploração nas entrevistas iniciais ganha com o uso de interfaces como mapas, esquemas, fotografias e vídeos, desde que façam sentido para os interlocutores e não sejam usados na função de roteiros. Mapas - prontos ou desenhados na hora e em conjunto - ajudam a apontar topônimos, marcos, caminhos e limites; fotografias atuais ou antigas despertam interesse e ensejam temas de conversa; maquetes deixam as pessoas curiosas e ajudam na identificação de aspectos do território a explorar.

Embora entrevistas qualitativas normalmente sejam gravadas e transcritas, as de caráter exploratório admitem outros procedimentos, pois sua tônica não está na compreensão matizada e aprofundada. Para revisar informações objetivas, sem analisar as falas literalmente, basta a gravação sem transcrição. Outra possibilidade é avaliar e sintetizar as entrevistas quase que de imediato, como no Participatory Rapid Appraisal e métodos afins. A abordagem descrita por Hartmann (2001), por exemplo, usada em projetos de pesquisa e planejamento para o desenvolvimento de áreas rurais, consiste na realização de um total de sessenta a noventa entrevistas de caráter exploratório ao longo de três dias. Elas são feitas por cerca de dez 
duplas de pesquisadores. Durante a entrevista, um dos membros de cada dupla conversa, enquanto o outro registra os conteúdos por escrito. Logo em seguida, a dupla discute esses conteúdos e já os condensa numa ficha. No quarto dia, as fichas das entrevistas de toda a equipe são cotejadas, e sistematiza-se o material em tópicos. No quinto dia, apresenta-se a síntese à população local para complementações, comentários e discussões. Trata-se de uma exploração mediante entrevistas qualitativas com boas chances de coletar temas e preocupações centrais para aquele grupo, sem passar por gravação, transcrição e análise detalhada.

\section{Etnografias}

A entrevista etnográfica como um tipo de direito próprio provém, conforme o nome diz, da etnografia. Já as entrevistas de caráter etnográfico, tais como entendidas aqui, são aquelas inseridas num trabalho de campo em que observação participante e entrevistas se apoiam mutuamente. O caráter etnográfico não pressupõe, portanto, uma pesquisa inteiramente pautada em métodos e premissas da etnografia, mas indica que o objeto, campo ou recorte da pesquisa é um contexto sócio-espacial concreto, ao qual os entrevistados pertencem e do qual o pesquisador já tem algum conhecimento. Procura-se a interação aprofundada para compreender perspectivas, ações e relações que não são evidentes à primeira vista e talvez venham a ser construídas ou verbalizadas pela primeira vez na entrevista (ou ao longo de uma série de entrevistas com a mesma pessoa). A seleção dos entrevistados se dá por suas características ou posições, de que o pesquisador tem noção pelo trabalho de campo realizado até aquele ponto.

Enquanto a transição entre caráter exploratório e etnográfico é fluida (assim como a passagem do pesquisador de novato a veterano em determinado contexto), o caráter etnográfico contrasta com entrevistas não relacionadas a nenhum contexto sócio-espacial concreto de pertencimento das pessoas entrevistadas. Numa pesquisa sobre arquitetura escolar, a entrevista com uma arquiteta especializada em projetos de escolas não terá caráter etnográfico. Se a mesma pesquisa incluir observação participante no cotidiano escolar, as entrevistas com professores, estudantes ou funcionários da escola observada podem ter esse caráter. O uso de um roteiro dependerá de outros aspectos, não do caráter etnográfico (na entrevista com a diretora da escola, talvez seja útil para sinalizar seriedade).

Alguns aspectos e tipos de pergunta usados em entrevistas etnográficas 'clássicas’ servem particularmente bem a pesquisas sócio-espaciais. Spradley (1979) recomenda começar qualquer entrevista como uma conversação amistosa, guiada pelos rituais que correspondem a esse tipo de encontro no respectivo contexto cultural. Perguntas descritivas são as mais fáceis de fazer e de responder (Como 
é seu dia a dia? Você pode me contar o que faz no seu trabalho?). Prestar atenção aos termos que a pessoa entrevistada usa nas suas descrições permite retomar esses termos no decorrer da conversa. Uma pergunta inicial que funcionou bem em entrevistas que fizemos numa favela de Belo Horizonte sobre a relação de pessoas idosas com a cidade foi: A senhora mora aqui há muito tempo? A resposta era curta, mas introduzia um tema. Em seguida, perguntávamos: Como a senhora veio para cá, para esta casa?. Isso quase sempre estimulava uma fala mais longa, uma pequena história em que apareciam, entre outras coisas, topônimos nativos e termos como invasão, vila e predinhos (não ocupação, aglomerado e conjunto habitacional).

Spradley também traz bons exemplos de como estimular descrições de processos, eventos e espaços, oferecendo ganchos à memória e à imaginação e - muito importante - tempo para pensar. Num desses exemplos, ele entrevista uma garçonete. A conversa já engrenou e algumas características do lugar de trabalho dela foram mencionadas. Então, em vez de dizer 'Por favor, descreva o bar onde você trabalha', Spradley (1979, pp. 65-66) expande a pergunta: "Sabe, você falou de vários lugares no Bar do Brady, o balcão, a estação das garçonetes, o andar de cima, o andar de baixo. Será que você pode descrever o interior do bar para mim? Por exemplo, se eu fosse cego e você me levasse ao Bar do Brady e fosse me falando onde estamos e tudo o que você está vendo, como seria?”. Note-se que essa expansão não faz uso de elementos que não tenham sido mencionados pela entrevistada, pois interessa a visão que ela tem desse lugar, não o inventário completo do estabelecimento.

\section{Narrativas}

Como sintetizam Sandra e Lewis Hinchman (1997, p. xvi), narrativas são "discursos com uma clara ordem sequencial que conecta eventos de uma maneira significativa para uma audiência definida e por isso oferecem insights sobre o mundo e/ou as experiências das pessoas nele”. Enquanto a narrativa oral é tema de uma vasta literatura especializada (da linguística, da história, da psicologia e de diversas outras áreas [cf. ELLIOT, 2005], a entrevista narrativa, como tipo específico, foi formulada primeiro por Fritz Schütze (1976) para uma pesquisa sobre estruturas de poder em comunidades locais. Com o pressuposto de que narrar histórias é uma competência humana que não depende da formação escolar, a intenção desse tipo de entrevista é driblar as usuais imposições de linguagem, temas e ordem de perguntas: uma pessoa conta uma história, que estrutura à sua maneira e com o seu léxico, enquanto a outra apenas escuta, sem fazer as reestruturações e reformulações típicas das entrevistas de matriz dialógica (sobre a desigualdade de poder nessas últimas [cf. ROSS, 2017; ANDERSON; JACK, 1991]. A narrativa segue um 
esquema autogerador porque, uma vez que alguém começa uma história, geralmente quer levá-la até o fim, dando-lhe o detalhamento ou a textura que, na sua perspectiva, é relevante para que a sequência de eventos faça sentido.

Por isso, Schütze (1976; cf. BAUER, 1996) divide a entrevista narrativa em etapas bem distintas. Há uma preparação prévia, em que o pesquisador explora o contexto em busca de temas do interesse e da experiência do entrevistado (temas imanentes, não exmanentes). A entrevista em si começa pela explicação de seu propósito e andamento, para então se lançar a pergunta grand tour, que incita a história. A etapa seguinte é a narrativa em si. O entrevistador escuta atentamente, sem interromper, apenas encorajando a pessoa entrevistada, até surgir uma coda, um sinal de finalização. Ao longo da narrativa, o entrevistador registra, mentalmente ou no papel, as perguntas que fará na terceira etapa. Schütze recomenda, para essa última parte, perguntas nos termos e eventos da narrativa ( $O$ que aconteceu depois que você...?) em vez daquelas relacionadas a opiniões, atitudes, causas ou contradições, como num interrogatório. Por fim, desligado o gravador, costuma surgir uma conversa mais relaxada, cujos conteúdos podem ajudar muito na interpretação da narrativa e devem ser registrados por escrito imediatamente após a entrevista.

Críticas a esse procedimento concentram-se nos pressupostos e na condução. Bauer (1996) argumenta que a forma da narrativa não elimina as imposições nem a modelação segundo uma agenda da pessoa entrevistada vis-à-vis aquilo que ela imagina que o outro espera ouvir. A narrativa é sempre direcionada a uma audiência, real ou imaginária (a entrevistadora, os pesquisadores que terão acesso ao material, pessoas que estão por perto etc.). Além disso, Schütze põe peso demasiado no momento inicial do encontro. A pergunta-chave é feita quando o clima ainda é de estranhamento e os interlocutores estão pouco à vontade (à diferença do início informal que Spradley recomenda). Também a atitude de não interferência tende a forçar ao limite as normas sociais de interação: uma pessoa se abre, 'entrega' tudo, enquanto a outra preserva sua subjetividade. Na prática, mesmo entrevistas que se pretendem puramente narrativas se desenvolvem de maneira menos ortodoxa.

Aqui, repito, não se trata de apresentar modelos e promover escolhas entre eles, mas de discutir variações a que se pode recorrer conforme o contexto e os objetivos de pesquisa. Nesse sentido, são entrevistas de caráter narrativo aquelas que favorecem a narração de histórias. A ênfase está na atenção aos momentos em que a pessoa entrevistada começa a contar um caso. Em vez de interrompê-la e tentar voltar logo aos temas planejados, cabe calar-se e ouvir atentamente, entendendo que narrativas podem expressar coisas que não seriam ditas de outra maneira. Isso vale em especial para grupos oprimidos, minoritários. Mais do que os diálogos, as 
narrativas deixam entrever ambiguidades entre um discurso dominante e a experiência dos dominados. Nas entrevistas que temos realizado em espaços urbanos e rurais com moradores de pouca formação escolar, à margem da "sociedade da entrevista”, as narrativas costumam surgir espontaneamente a partir de todo tipo de pergunta. A pessoa entrevistada começa com uma palavra ou expressão curta que imagina ser a resposta 'certa' (sim, é isso, foi mesmo) e então se põe a contar um caso que, na realidade, contradiz aquela interjeição inicial. Para usar uma metáfora de Kathryn Anderson e Dana Jack proveniente de entrevistas com mulheres, é como se as narrativas falassem em dois canais:

A discussão de uma mulher sobre sua vida pode combinar duas perspectivas separadas, frequentemente conflitantes: uma está enquadrada em conceitos e valores que refletem a posição dominante dos homens na cultura, e outra é informada pelas realidades mais imediatas da experiência pessoal de uma mulher. Onde a experiência não 'encaixa' em significados dominantes, conceitos alternativos podem não estar disponíveis de imediato. Portanto, inadvertidamente, as mulheres costumam silenciar os próprios pensamentos e sentimentos quando tentam descrever suas vidas nos termos familiares e publicamente aceitos de conceitos e convenções vigentes. [...] precisamos aprender a ouvir em estéreo, captando claramente tanto o canal dominante quanto o canal silenciado, e sintonizando cada um cuidadosamente para compreender a relação entre eles. (ANDERSON; JACK, 1991, p. 11.)

Outro aspecto que torna as narrativas preciosas para as pesquisas sócio-espaciais é que, além da sequência temporal, elas contêm sequências espaciais (aliás, deixadas de lado pela maioria dos métodos de análise de narrativas [cf. ELLIOT, 2005]. Eventos acontecem em lugares e, querendo ou não, quem conta um caso fala de características e relações espaciais. Assim, por exemplo, uma pesquisa realizada no Grupo MOM, com mulheres que trabalham de forma cooperativa, fez uso de entrevistas de caráter predominantemente narrativo para decifrar as relações entre espaços domésticos e espaços de produção (SILVA, 2014). No contexto de um projeto de centro comunitário num quilombo rural, que deveria levar em conta uma grande festa religiosa realizada ali todos os anos, só compreendemos a espacialidade dessa celebração por meio das narrativas dos moradores, ao passo que falharam totalmente nossas ingênuas solicitações iniciais de que enunciassem equipamentos e espaços necessários ao evento.

Domingo mesmo eu tava numa [...] Porque às vezes... Tenho um [bis] neto que não é muito... que faz as coisas que eu não gosto [tráfico]. Mas eu não sou de ficar falando, nem ficar brigando, ficar xingando. 
Aí eu tava ruim. Falei: Meu Pai, o que é que eu faço? Aí a menina falou assim, na hora que eu tava descendo: Ih, sua casa tá cheia de gente. Gente que eu não gosto. Aí então eu falei: Meu Pai, ir lá pra ficar olhando pra cara daquele povo? Porque ele [o bisneto] tava mexendo com uma construçãozinha dele lá e ia só gente que eu tava... que eu não gostava. Aí eu fui pra igreja e falei assim: O que é que eu vou fazer? No fim, peguei o ônibus, fui embora lá pra cidade [o centro]. Fui pro parque. Chegou no parque... Mas fiquei triste quando cheguei no parque. Tinha muito tempo que eu não ia no parque municipal. Fiquei triste, muito mendigo, malcheiroso. [...] sentei e fiquei com a mão assim [cobre o rosto com as mãos]. Veio um casalzinho [...]. Aí falou assim: Ó senhorinha, tá passando mal? Falei: Tô não, minha filha. Porque eu tava nervosa, né? Fui lá pra chorar. Quando às vezes tá demais, eu vou pra chorar. Não vi os pato, não vi mais nada. Estão querendo tirar os gatos, e a gente [...] Fiquei triste com isso, né? Aí eu fiquei assim, pensando na vida. [...] Aí saí dali, fui pra igreja São José. Assisti à missa. Andei um mucadinho, fui até perto da rua Tupis, voltei. Aí quando foi seis horas, que eu cheguei em casa, eles já tinham ido embora. Aí fui fazer minhas coisas. [...] Porque eu sou uma pessoa que... assim, eu, sozinha, pra resolver tudo. Eu criei os cinco filhos, com mais quatro da minha filha, nove, e já casei meus filhos tudo, casei os netos. Agora os bisnetos ficam rodeando, fazendo coisa que eu não tô aguentan... que eu não tô gostando! Aí eu saio um pouquinho e volto. Aí alenta e eu venho embora. Porque eu tenho medo de ficar batendo de frente com ele. E eu não tô mais na época de ficar batendo de frente com ninguém.

Sem comentar as muitas inferências que esse caso suscita quanto à situação de uma mulher idosa e pobre, atenho-me à estrutura da narrativa e à maneira como o espaço comparece. Há todos os elementos que o artigo seminal de Labov e Waletzky (1967) indica como típicos - mas não imprescindíveis - de uma narrativa: orientação, complicação, avaliação, resolução e coda. A orientação situa os ouvintes no contexto de tempo, espaço, pessoas e situação da narrativa ("Domingo mesmo"; "Tenho um neto"; "não sou de ficar falando”). Na complicação, a narradora conta, numa sequência mais ou menos cronológica, o que aconteceu. A avaliação enfatiza o significado que ela atribui à sequência de eventos ("eu, sozinha, pra resolver tudo”), expressando o sentimento de que as décadas de esforço para manter a família não foram recompensadas nem são respeitadas. A resolução diz o que aconteceu no fim das contas ("Aí alenta e eu venho embora”). A narrativa fecha com uma coda que traz a conversa de volta ao tempo presente ("E eu não tô mais na época de ficar batendo de frente com ninguém”).

A primeira referência ao espaço da narrativa está na fala: “eu tava descendo...” A senhora havia ido a algum lugar na manhã de domingo e estava voltando para casa. Depois aparecem a casa, uma igreja na favela, o ônibus, o parque munici- 
pal, a igreja São José e a rua Tupis. Implicitamente, são tocados os espaços públicos da favela - que não lhe oferecem lugar para algumas horas de sossego -, ruas do centro da cidade que lhe são familiares e o parque municipal de sua memória ou de sua imaginação, em que não havia mendigo nem gatos e que não era malcheiroso. Pode-se inferir que o bisneto estava autoconstruindo no terreno ou na laje de sua casa com a ajuda de amigos. Todos esses espaços, com os processos e significados a eles relacionados, seriam temas a tentar expandir ao final da narrativa.

Há muitas possibilidades para apoiar ou estimular narrativas por meio de interfaces, desde que não configurem roteiros. No final dos anos 1970, num projeto na cidade mineira de Tiradentes, o economista chileno Max-Neef (1982, pp. 184-188) e seus colegas fizeram - entre muitas outras ações - uma pesquisa de fotografias da cidade e dos moradores. Passaram meses indo de casa em casa, conversando com as pessoas e vendo fotos antigas. Depois copiaram, restauraram e ampliaram 120 delas (das seiscentas coletadas) para uma grande exposição, cobrindo cem anos de história. A cidade inteira, incluindo os mais idosos, foi à inauguração, que acabou se tornando uma rememoração coletiva das narrativas do lugar.

\section{Focos}

O método denominado entrevista focada remonta aos Estados Unidos da década de 1940 e às pesquisas sobre os efeitos dos meios de comunicação de massa, por sua vez motivadas pela demanda de propaganda de guerra. Ele foi desenvolvido por Robert Merton e Patricia Kendall, inicialmente no âmbito do Radio Research Project, cuja coordenação era de Paul Lazerfeld e do qual participaram também intelectuais emigrados de Frankfurt, como Horkheimer e Adorno. O método provém de um contexto de pesquisas sociais em que se tratava de elucidar relações de causa e efeito, estímulo e resposta; o que, em última análise, deveria servir para dirigir o público. Daí não surpreende o sucesso de suas derivações posteriores no marketing, como o chamado grupo focal, popularizado na década de 1980 (cf. Merton [1987] e Merton, Fiske e Kendall [1990] acerca das diferenças entre entrevista focada e grupo focal).

O termo entrevista focada se deve ao fato de ela se estruturar para um foco ou tema muito bem delimitado e bastante restrito, explorando, em detalhes e com precisão, a experiência subjetiva do entrevistado. Temas abrangentes não se prestam a entrevistas focadas. Poderiam constituir focos, por exemplo, um episódio de remoção, um mutirão, uma audiência pública, um manual, uma ferramenta ou uma praça, mas não assuntos amplos como a relação entre ocupações urbanas e poder público, a cultura construtiva ou a política habitacional. Merton e Kendall (1946, p. 541) sintetizaram as premissas do método nos seguintes termos: 
1. As pessoas entrevistadas participaram de uma situação concreta particular: elas viram um filme, ouviram um programa de rádio, leram um panfleto, artigo ou livro, ou participaram de um experimento psicológico ou de uma situação social não controlada, mas observada.

2. Estrutura geral, elementos e padrões hipoteticamente significantes dessa situação foram analisados previamente pelo pesquisador. Mediante essa análise de conteúdo, ele chegou a um conjunto de hipóteses sobre o sentido e os efeitos de determinados aspectos da situação.

3. Baseado nessa análise, o pesquisador elaborou um guia de entrevista definindo as principais áreas de indagação e as hipóteses que situam a pertinência dos dados a obter na entrevista.

4. A entrevista em si é focada nas experiências subjetivas das pessoas expostas à situação pré-analisada. O leque de suas respostas a tal situação permite ao pesquisador: a) testar a validade das hipóteses derivadas da análise de conteúdo e da teoria da psicologia social; b) encontrar respostas imprevistas à situação, gerando novas hipóteses.

Trata-se de encontrar elementos para explicar correlações entre estímulos e respostas, no lugar de somente constatá-las, como era comum nas pesquisas quantitativas a que Merton e Kendall contrapõem a entrevista focada. Imagine-se, por exemplo, que, numa comunidade, a distribuição de convites para uma audiência pública tenha tido pouca adesão. Em vez de apenas especular acerca dos motivos, entrevistas focadas serviriam para descobrir como as pessoas de fato receberam e entenderam aquele convite, que aspectos foram relevantes para que o aceitassem ou ignorassem, que subgrupos reagiram àquilo de maneira diversa dos demais e por que razão, e assim por diante. Os pesquisadores estabeleceriam de antemão suas hipóteses (o texto não era claro, o horário era ruim, os convites foram feitos com muita antecedência etc.), que seriam testadas nas entrevistas. Mas essas também produziriam possíveis explicações que, antes, nem sequer eram imaginadas pelos pesquisadores.

A dificuldade está em testar hipóteses prévias sem induzir os entrevistados nem interditar hipóteses novas. Partindo da análise de numerosas transcrições de entrevistas focadas, Merton e Kendall (1946) apontam os erros mais comuns e deles derivam quatro "critérios" para uma condução propícia ao fornecimento de boas explicações: não direcionamento, especificidade, amplitude e profundidade.

O critério do não direcionamento significa que a pessoa entrevistada escolhe e introduz os tópicos, enquanto o entrevistador faz apenas questões realmente abertas ( $\mathrm{O}$ que chamou sua atenção neste panfleto?) e nunca perguntas com opções de resposta (Você prefere isso ou aquilo?). Assim, a entrevista "dá ao sujeito uma oportunidade de se expressar sobre questões que para ele são de significação 
central em vez daquelas que o entrevistador presume que sejam importantes" (MERTON; KENDALL, 1946, p. 545). O entrevistador abstém-se de manifestações didáticas, polêmicas ou desafiadoras, que provocariam atitude defensiva ou autocensura da pessoa entrevistada. Se ela dirigir perguntas ao entrevistador, estas devem ser devolvidas. Digamos que o foco da entrevista seja o uso de certo material de construção. Um entrevistado acha que o entrevistador tem conhecimento técnico e lhe faz uma pergunta: Afinal, o que é que tem que pôr nessa massa? Em vez de começar a explicar, o entrevistador deve devolver a pergunta: Você quer dizer que essa argamassa deve ser diferente da comum? Se, em vez disso, ministrasse uma pequena aula, poderia levar o entrevistado a omitir tudo o que, a seu ver, parecesse 'errado' ao entrevistador. As informações mais importantes - sobre como a pessoa de fato entende e usa determinado material - ficariam interditadas de antemão.

O critério da especificidade significa tentar descobrir, o mais precisamente possível, que aspectos da situação em foco levaram às percepções da pessoa entrevistada. Uma maneira de fazer isso é reapresentar a situação à medida que ela é recordada, eventualmente com interfaces como imagens, espaços, documentos e outros objetos. No exemplo acima, sobre o uso de um material de construção, a entrevista poderia acontecer num canteiro de obras em que o material estivesse sendo usado naquele momento. Se o foco fosse a experiência de uma praça, poderia acontecer nesse espaço; se fosse um mutirão, poder-se-ia recorrer a fotos do evento. Outra maneira de apoiar a especificação é formular perguntas focadas. Por exemplo, uma entrevistada diz de certo evento participativo: Esse pessoal da prefeitura já vem com tudo decidido. 0 termo vem (não veio) conota uma percepção genérica. Caberia perguntar: O que lhe deu essa impressão nessa reunião? A pergunta traz a atenção de volta ao evento particular e é um pedido de especificação dos aspectos que ali, naquele evento, provocaram ou reforçaram a ideia de uma participação apenas legitimadora.

Quanto à amplitude, trata-se de cuidar para que muitas facetas da situação em foco sejam abordadas, mas, de novo, sem impor referências exmanentes. A habilidade está em perceber os momentos em que a pessoa entrevistada passa de uma faceta a outra, e compreender por que faz isso: falta de interesse, a sensação de já ter esgotado aquele aspecto ou algum desconforto em falar a respeito. Se a pessoa não introduzir, ela mesma, uma nova faceta, o entrevistador pode fazer a transição, de preferência a partir de algo que o entrevistado disse. Essa técnica de amarrar uma nova pergunta a uma referência anterior também serve para limitar digressões e manter a conversa no foco. Quando alguém deixa de falar de um aspecto por constrangimento ou mal-estar, pode-se tentar voltar a ele em outro momento, usando a mesma técnica. De qualquer modo, é melhor abrir mão de alguns tópicos do que abordá-los apenas pro forma. 
O critério da profundidade relaciona-se à ação de ajudar o entrevistado a expressar, para além da mera aprovação ou reprovação, como a situação em foco foi experienciada no seu contexto pessoal. Fundamental nisso é a habilidade de distinguir comentários apenas circunstanciais, sem maior relevância, e comentários que indicam significados relevantes. Uma boa maneira de estimular alguém a expressar tais significados é perguntar pelos seus sentimentos. Pequenas variações na pergunta podem levar a respostas de teor mais objetivo (O que você lembra do dia da remoção?) ou mais aprofundadas quanto às experiências subjetivas (Como você se sentiu no dia da remoção?).

Entrevistas focadas pressupõem a elaboração de um guia com possíveis perguntas sobre os tópicos correlatos às hipóteses prévias, de modo que não seja necessário improvisar. No entanto, esse guia jamais deve ser aplicado mecanicamente. Ao contrário da entrevista semiestruturada, que exige fazer sempre as mesmas perguntas, aqui não se introduzem temas antes que a pessoa entrevistada o faça. E, mesmo quando ela toca num assunto previsto no guia, cabe escutar com atenção e aguardar antes de recorrer a uma pergunta pré-formulada. Importa mais ouvir do que administrar o guia. Apenas ao final o entrevistador pode perguntar a respeito de tópicos presentes no guia e dos quais não se falou espontaneamente. Ainda assim, o guia não desempenha a função de roteiro nem define que a entrevista só se conclua depois que todos os itens tiverem sido 'despachados'.

Com as devidas ressalvas quanto ao contexto de formulação do método da entrevista focada, considero que as recomendações de Merton e Kendall (1946) - a precedência de termos e temas do entrevistado, a primazia da escuta sobre o guia, a atenção aos contextos pessoais de significação de um fenômeno - valem para muitas situações de entrevistas qualitativas. Uma entrevista sócio-espacial de caráter focado seria a tentativa de compreender a experiência de um fenômeno concreto particular mediante o diálogo aberto e, ao mesmo tempo, mais concentrado do que em conversas corriqueiras ou entrevistas com outras ênfases. O caráter focado indica a proposta - nada óbvia - de unir concentração e liberdade de expressão, ou seja, fechamento (no foco) e abertura (na escuta). Porém, contra a tentação do marketing, entendo que entrevistas de caráter focado não se aplicam a esclarecimentos acerca de situações futuras (planos ou projetos), pelo simples e óbvio fato de que as pessoas entrevistadas não terão tido nenhuma experiência dessas situações. Por exemplo, entrevistas com esse caráter podem enfocar um processo participativo ou a forma de apresentação de um projeto (desenho, maquete, vídeo, anúncio), mas não a situação projetada em si. Podem ajudar a esclarecer por que ninguém frequenta certa praça, mas não podem indicar se esse ou aquele projeto faria com que passasse a ser frequentada. 


\section{Especialistas e experts}

Entrevistas com pessoas em posições privilegiadas são tema de debate nas ciências sociais de língua inglesa desde o trabalho de Lewis Dexter (1970), Elite and Specialized Interviewing. A sociologia de língua alemã vem discutindo questões metodológicas semelhantes desde a década de 1990, mas sob o título Experteninterview ou entrevista com experts (LITTIG, 2008). Cristalizaram-se aí posições díspares acerca de como definir os protagonistas desse tipo de entrevista, isto é, a elite, o especialista, o expert ou perito. Bogner e Menz (2002) agruparam as diversas perspectivas em conservadoras, voluntaristas e construtivistas, propondo ainda uma definição alternativa, que me parece a mais interessante para pesquisas sócio-espaciais.

$\mathrm{Na}$ perspectiva conservadora, experts são autoridades em determinado campo, do qual detêm um conhecimento relativamente raro, fruto da divisão do trabalho, do acesso privilegiado a informações e de uma competência de síntese ou visão global. À diferença do conhecimento cotidiano, o conhecimento do expert seria estruturado e reflexivo por natureza, e seus portadores seriam capazes de comunicá-lo objetiva e sistematicamente. A entrevista com o expert visaria à obtenção de tais sistematizações.

Na perspectiva voluntarista, pelo contrário, todo ser humano é considerado expert ou especialista em alguma coisa: no mínimo, dispõe de conhecimento exclusivo acerca da própria circunstância de vida. Gläser e Laudel (2009, p. 12), por exemplo, tendem a essa definição voluntarista, pois apontam que o termo expert "descreve o papel específico do entrevistado como fonte de um conhecimento especial sobre uma situação social a ser investigada”, o que valeria para todas as pessoas participantes da situação em questão, não importando seu status nem suas possibilidades de ação. A entrevista teria como finalidade obter a perspectiva subjetiva do entrevistado sobre o tema. A ideia parece democrática, mas de fato negligencia hierarquias reais entre tipos de conhecimento e posições sociais (além de ser tão genérica que pouco acrescenta à discussão de procedimentos de entrevista).

Na perspectiva construtivista, o interesse de pesquisa determina quem será ou não considerado expert, conforme a posição que alguém ocupa em relação a esse interesse. Meuser e Nagel (1991) argumentam que experts são pessoas atuantes em funções de decisão e condução de processos sociais, e que a entrevista objetiva obter suas perspectivas como profissionais, não como sujeitos particulares afetados pelo processo. Na prática, a seleção desses experts se apoia na fama dos possíveis candidatos no respectivo meio social (cargos, títulos e outros sinais de legitimação). Enquanto o conceito voluntarista corre o risco de obscurecer hierarquias reais, a definição construtivista corre o risco de acatá-las acriticamente. 
Por exemplo, se o objeto da pesquisa fosse certo processo de planejamento urbano participativo, os experts da abordagem conservadora seriam professores universitários especializados no assunto, os da abordagem voluntarista seriam quaisquer participantes do processo, e os da abordagem construtivista seriam detentores de cargos nos órgãos do Estado ou lideranças de movimentos sociais.

Bogner e Menz (2002) propõem, então, uma definição que parte da construtivista, mas cuja prioridade está na relevância social do conhecimento do entrevistado. Eles consideram que o conhecimento do expert compreende uma dimensão técnica (escolar) e uma dimensão processual (que diz respeito a interações, fluxos e rotinas, e que se adquire somente pela experiência), assim como uma dimensão interpretativa (visões, convicções pessoais).

\begin{abstract}
Nesse sentido, experts podem ser entendidos como pessoas que - a partir de um conhecimento prático ou empírico específico, relacionado a um âmbito de problemas claramente definível - criaram a possibilidade de, com suas interpretações, estruturar o campo de ação concreto de maneira significativa e orientadora da ação [de outras pessoas]. (BOGNER; MENZ, 2002, p. 45.)
\end{abstract}

Experts conhecem - ao menos razoavelmente - sua matéria, mas importa o fato de que conhecem uma prática e são capazes de influenciá-la conforme suas visões. A entrevista com eles visa à aproximação com as dimensões processual e interpretativa do seu conhecimento, porque é delas que decorre a estruturação de um campo de ação (empresa, órgão público, território etc.). Na maioria das vezes, tais experts já dispõem de um discurso público e não precisam de muito estímulo para reproduzir as falas que empregam habitualmente para explicar ou justificar suas posições. Por outro lado, princípios ou crenças com que efetivamente orientam as ações de um campo costumam ser tácitos. A ideia é fazer da entrevista uma interação em que esses princípios sejam articulados. Trata-se de entrevistas cujo objetivo não é a compreensão das subjetividades por si mesmas, e sim a geração de teorias acerca de situações ou processos sociais. Como uma pessoa vê, processa ou interpreta os acontecimentos importa na medida em que ela os influencia.

Essa definição me parece pertinente para entrevistas de caráter especializado no contexto das pesquisas sócio-espaciais por duas razões. A primeira é que, à diferença das abordagens voluntaristas, ela não tem como premissa a participação direta das pessoas entrevistadas no processo social investigado. A produção do espaço é em grande parte determinada por agentes externos - legitimados política ou tecnicamente - que não vivem os processos que engendram nem são afetados por eles. A segunda razão é que, diferentemente das abordagens conservadoras e da 
maioria das abordagens construtivistas, a definição de Bogner e Menz (2002) não pressupõe que o entrevistado fale 'enquanto profissional' e se abstenha de falar 'enquanto sujeito particular’. Ou seja, ela não tem como premissa entrevistados habituados a uma distinção límpida entre vida privada e vida pública ou profissional, tal como é característica dos setores tidos como mais desenvolvidos das sociedades modernas. As muitas entrevistas que já fizemos com pessoas pouco escolarizadas pouco 'modernas' nesse sentido específico - mostram que abstrair da vida privada para elucidar determinados processos faria pouco sentido ali. Ao mesmo tempo, inúmeras decisões tomadas nos campos burocrático, técnico e político sobre a produção do espaço são determinadas não (apenas) por dados e interesses objetivos, mas (também) por convicções, visões de mundo e preconceitos.

Então, seguindo a definição citada acima, chamo aqui de caráter especializado a ênfase de uma entrevista no conhecimento objetivo e subjetivo do entrevistado a respeito de um campo de ação específico, considerando que esse conhecimento é relevante para orientar os agentes daquele campo. Pessoas com tais características podem ser lideranças, porta-vozes ou detentoras de cargos oficiais, mas podem estar igualmente em posições de menos evidência. Descobrir quem são exige conhecer o campo em que atuam.

A interação nas entrevistas de caráter especializado depende muito da maneira como a pessoa entrevistada vê a entrevistadora, em relação tanto à competência técnica como ao poder ou à orientação normativa que lhe atribui. Nenhuma liderança de um movimento social, por exemplo, concederá uma entrevista sem formar uma opinião sobre a posição política do interlocutor ou sobre as possíveis consequências da interlocução. Cabe atentar então para algumas situações de percepção da entrevistadora pela entrevistada (também aqui sigo a tipologia de Bogner e Menz [2002], com algumas variações). Cada uma delas traz vantagens e desvantagens quanto ao que mais interessa: a construção e articulação verbal das práticas e visões sobre um campo de ação.

Uma entrevistadora percebida como colega, especialista na mesma área e de status semelhante, favorece um diálogo horizontal. Há uma terminologia comum, muitas explicações são dispensáveis e a pessoa entrevistada também fará perguntas. A desvantagem é que a entrevista pode desembocar num debate técnico sem chegar às dimensões processual e interpretativa do conhecimento do entrevistado. Já uma entrevistadora identificada como alguém de status equivalente, porém de outra área de atuação, favorece mais explicações, pois deixa de ser óbvia a familiaridade com práticas e premissas.

A essas duas situações contrapõe-se a entrevistadora vista como leiga, de status inferior (gênero e idade importam aqui), o que tende a provocar atitudes pa- 
ternalistas e monológicas, mas, por isso mesmo, pode ser favorável à explicitação de conhecimento processual e interpretativo. A pessoa entrevistada fica à vontade porque não precisa provar nada e se dispõe a responder a perguntas aparentemente ingênuas, que às vezes geram as respostas mais interessantes. Há, porém, o risco de desinteresse por parte do entrevistado e o fato de a entrevistadora ter poucas chances de conduzir os temas da conversa. Inversamente, a entrevistadora tida por autoridade em posição social ou tecnicamente superior é percebida como um avaliador. $O$ entrevistado teme que o fato de fornecer certas informações tenha consequências práticas, e isso provoca desconfiança, discursos de legitimação e omissão de problemas ou críticas, numa atitude submissa ou agressiva. No melhor dos casos, a entrevista revela estratégias do entrevistado para defender interesses do seu campo, mas não como essa pessoa vê o próprio campo de ação e como o influencia.

Quanto às posições políticas, um entrevistador visto como cúmplice, companheiro de luta, aumenta a propensão a revelações, contudo apresenta a desvantagem de que não se podem fazer perguntas ingênuas, pois contradiriam a premissa da cumplicidade. Já o entrevistador visto como oponente político provoca hostilidade. Isso pode até produzir argumentações esclarecedoras quanto à dimensão interpretativa do conhecimento do especialista, entretanto na maioria dos casos não é boa premissa.

Para entrevistas cuja ênfase esteja no caráter especializado, no sentido acima, cabe uma preparação cuidadosa. É preciso conhecer o campo de ação para saber quem entrevistar, como ter boas chances de que essas pessoas concedam as entrevistas, que percepção a situação provavelmente provocará, como formular perguntas relevantes e como distinguir as dimensões técnica, processual e interpretativa. Esse conhecimento prévio não precisa ser explicitado em sua totalidade. Mencionar alguns fatos ou termos daquele contexto às vezes é suficiente para fazer a conversa fluir. Um roteiro ajuda quando o entrevistador tende a ser percebido como socialmente inferior, mas não quando tende a ser considerado autoridade.

\section{Um balanço}

As variações de ênfase das entrevistas em pesquisas sócio-espaciais, tais como apontadas nos itens precedentes, seguem, grosso modo, uma ordem do menor para o maior conhecimento prévio do campo, da situação ou do processo a que a pergunta de pesquisa se dirige. Entrevistas de caráter exploratório podem ser feitas quando não se sabe nada; as de caráter etnográfico estão inseridas num contexto sócio-espacial e avançam com a observação direta desse contexto; as de caráter narrativo demandam pelo menos a proposição de uma pergunta inicial que 
faça sentido e seja de interesse para as pessoas entrevistadas; as de caráter focado pressupõem que se estabeleçam hipóteses prévias acerca de possíveis respostas; e as de caráter especialista ou especializado exigem conhecimento do campo em que o expert atua. As possibilidades de combinação derivam - também apenas grosso modo - dessas relações de proximidade ou de distância.

Unindo os extremos, teríamos entrevistas de caráter exploratório com experts, isto é, entrevistas iniciais com pessoas especialistas no campo investigado. Embora essa seja uma prática bastante comum, tais entrevistas de fato funcionam mais como consultorias no processo de pesquisa do que como fontes de dados a analisar e interpretar. Fornecem pistas e ajudam a obter uma visão global que talvez só poderia ser alcançada depois de longas observações ou muitas horas de leitura, mas implicam sempre o risco de adoção ingênua de uma visão particular sobre aquele campo, em detrimento de outras visões. Além disso, não podem contar como fontes empíricas para a compreensão da estruturação de um campo de ação, porque quem faz a entrevista não é, ainda, capaz de fazer distinção entre as dimensões técnica, processual e interpretativa daquilo que o entrevistado lhe diz.

Algo semelhante vale para a combinação de caráter exploratório e caráter focado. Talvez a compreensão de uma situação concreta e particular (o foco) exija entrevistas exploratórias preliminares para que os pesquisadores tenham noção das facetas daquela situação e consigam estabelecer hipóteses a testar, mas o aprofundamento e o detalhamento do foco não equivalem a essa exploração inicial.

Já entre entrevistas de caráter exploratório e de caráter etnográfico a transição é fluida, como dito acima. O mesmo vale para a relação entre caráter etnográfico e narrativo. É perfeitamente possível - e promissor - estimular a 'contação de casos' numa entrevista que faz parte de uma investigação com observação direta e participante de um contexto sócio-espacial concreto (desde que não se adote a postura ortodoxa da entrevista narrativa 'clássica'). Também entrevistas de caráter focado podem se valer de narrativas, com a restrição - por vezes difícil de manter - ao foco. A combinação do caráter etnográfico com um foco me parece menos plausível, porque a interação entre pessoas entrevistadas e entrevistadoras tende a diferir bastante (da conversa quase 'normal' à conversa bem circunscrita e concentrada).

Sejam quais forem as combinações e variações pertinentes a cada pesquisa sócio-espacial - que certamente não se restringem às ênfases indicadas acima -, cabe considerar a relação entre os dados obtidos e o uso que será feito deles na análise e na interpretação. Da mesma maneira que a condução das entrevistas em si, a contextualização daquilo que as pessoas dizem depende do conhecimento já adquirido acerca do campo em estudo. Apenas assim se pode, ao menos, tentar 
compreender em que medida suas assertivas, narrativas, opiniões ou declarações são condicionadas pela situação da entrevista e pela maneira como a pesquisadora ou o pesquisador é visto, e em que medida ajudarão a responder a uma pergunta de pesquisa. Nesse sentido, é improvável que uma pesquisa sócio-espacial possa basear-se somente em entrevistas e dispensar outras fontes de dados, como observação direta, imagens, bibliografia, registros históricos, levantamentos físicos e, também, experimentos.

\section{Agradecimentos}

Agradeço ao Conselho Nacional de Desenvolvimento Científico e Tecnológico (CNPq), à Coordenação de Aperfeiçoamento de Pessoal de Nível Superior (Capes) e à Financiadora de Estudos e Projetos (Finep) pelo financiamento das pesquisas que deram origem a este trabalho.

\section{Referências bibliográficas}

ANDERSON, K.; JACK, D. C. Learning to Listen: Interview Techniques and Analyses. In: GLUCK, S. B.; PATAI, D. Women's words: The Feminist Practice of Oral History. Nova York: Routledge, 1991, p. 11-26.

ASCHMANN, M.; WIDMANN, J. Meinungen, die keine sein können: ein Befragungsexperiment zu "Pseudo-Opinions". ZA-Information/Zentralarchiv für Empirische Sozialforschung, $\mathrm{n}$. 19, 1986, p. 80-83.

ATKINSON, P.; SILVERMAN, D. Kundera's Immortality: the Interview Society and the Invention of the Self. Qualitative Inquiry, n. 3, 1997, pp. 304-25.

BARTON, A. H. Bringing Society Back In: Survey Research and Macro-methodology. American Behavioral Scientist, v. 12, n. 2, nov. 1968, pp. 1-9.

BAUER, M. The Narrative Interview: Comments on a Technique for Qualitative Data Collection. Londres: London School of Economics and Political Science, Methodology Institute, 1996.

BEAUD, S.; WEBER, F. Guia para a pesquisa de campo. Produzir e analisar dados etnográficos. Petrópolis: Vozes, [1997] 2014.

BISHOP, G.; OLDENDIEK, R.; TUCHFABER, A.; BENNETT, S. Pseudo Opinions on Public Affairs. Public Opinion Quarterly, v. 44, n. 2, 1980, pp. 198-209.

BOGNER, A.; MENZ, W. Das theoriegenerierende Experteninterview Erkenntnisinteresse, Wissensformen, Interaktion. In: BOGNER, A.; LITTIG, B.; MENZ, W. Das Experteninterview. Theorie, Methode, Anwendung. Wiesbaden: Springer, 2002, pp. 33-70.

BOURDIEU, P. Compreender. In: . A miséria do mundo. Petrópolis: Vozes, [1993] 2003, pp. 693-713. 
BOURDIEU, P; CHAMBOREDON, J. C.; PASSERON, J. C. O ofício do sociólogo: Metodologia da pesquisa na sociologia. Petrópolis: Vozes, [1968] 2007.

DEXTER, L. A. Elite and Specialized Interviewing. Evanston: Northwestern University Press, 1970.

ELLIOT, J. Using Narrative in Social Research. Qualitative and Quantitative Approaches. Londres: Sage Publications, 2005.

GLÄSER, J.; LAUDEL, G. Experteninterviews und qualitative Inhaltsanalyse als Instrumente rekonstruierender Untersuchungen. Wiesbaden: Verlag für Sozialwissenschaften, 2009.

GOODMAN, L. Snowball Sampling. The Annals of Mathematical Statistics, v. 32, n. 1, 1961, pp. 148-70.

GUBRIUM, J. F.; HOLSTEIN, J. A. From the Individual Interview to the Interview Society. In: . Handbook of Interview Research. Londres: Sage, 2001, pp. 2-32.

HARTMANN, P. Qualitative Interviews nach der PRA-Methode - Mit Moderationstechniken in nur sieben Tagen von der Interviewerschulung bis zur Präsentation der Ergebnisse. Sozialwissenschaften und Berufspraxis, v. 24, n. 2, 2001, pp. 165-70.

HERZOG, H. Interview Location and Its Social Meaning. In: GUBRIUM, J. F.; HOLSTEIN, J. A.; MARVASTI, A. B.; McKINNEY, K. D. The Sage Handbook of Interview Research. 2nd edition. Los Angeles: Sage, 2012, pp. 207-218.

HINCHMAN, L. P.; HINCHMAN, S. K. Introduction. In: HINCHMAN, L. P.; HINCHMAN, S. K. Memory, Identity, Community: The Idea of Narrative in the Human Sciences. Nova York: State University of New York, 1997, pp. xiii-xxxii.

HOPF, C. Die Pseudo-Exploration - Überlegungen zur Technik qualitativer Interviews in der Sozialforschung. Zeitschrift für Soziologie, v. 7, n. 2, 1978, pp. 97-115.

JOHNSON, J. M.; ROWLANDS, T. The Interpersonal Dynamics of In-depth Interviewing. In: GUBRIUM, J. F.; HOLSTEIN, J. A.; MARVASTI, A. B.; McKINNEY, K. D. The Sage Handbook of Interview Research. 2nd edition. Los Angeles: Sage, 2012, pp. 99-114.

KVALE, S. InterViews: An Introduction to Qualitative Research Interviewing. Los Angeles: Sage, 1996.

LILLRANK, A. Managing the Interviewer's Self. In: GUBRIUM, J. F.; HOLSTEIN, J. A.; MARVASTI, A. B.; McKINNEY, K. D. The Sage Handbook of Interview Research. 2nd edition. Los Angeles: Sage, 2012, pp. 281-94.

LITTIG, B. Interviews mit Eliten - Interviews mit ExpertInnen: Gibt es Unterschiede? Forum Qualitative Sozialforschung/Forum: Qualitative Social Research, v. 9, n. 3, 2008.

MAX-NEEF, M. From the Outside Looking In: Experiences in “barefoot economics”. Londres e New Jersey: Zed Books, 1982.

McINTOSH, M. J.; MORSE, J. M. Situating and Constructing Diversity in Semi-Structured Interviews. Global Qualitative Nursing Research, 2015, pp. 1-12.

MERTON, R. K. The Focussed Interview and Focus Groups: Continuities and Discontinuities. The Public Opinion Quarterly, v. 51, n. 4, 1987, pp. 550-66. 
MERTON, R. K.; KENDALL, P. L. The Focused Interview. American Journal of Sociology, v. 51, n. 6,1946, p. 541-57.

MERTON, R. K.; FISKE, M.; KENDALL, P. L. The Focused Interview. A Manual of Problems and Procedures. Nova York: The Free Press, [1956] 1990.

MEUSER, M.; NAGEL, U. ExpertInneninterviews - vielfach erprobt, wenig bedacht: Ein Beitrag zur qualitativen Methodendiskussion. In: GARZ, D.; KRAIMER, K. Qualitativ-empirische Sozialforschung: Konzepte, Methoden, Analysen. Opladen: Westdeutscher Verlag, 1991, pp. 441-71.

ROSS, K. Making Empowering Choices: How Methodology Matters for Empowering Research Participants. Forum Qualitative Sozialforschung/Forum: Qualitative Social Research, v. 18, n. 3, 2017, s.p.

SCHÖRLE, E. Das Lach-Seminar. Anmerkungen zu Theorie und Praxis bei Adorno. WerkstattGeschichte, n. 35, Hamburgo, Ergebnisse Verlag, 2003, pp. 99-108.

Zur Hervorlockung und Analyse von Erzählungen thematisch relevanter Geschichten im Rahmen soziologischer Feldforschung. Dargestellt an einem Projekt zur Erforschung kommunaler Machtstrukturen. In: WEYMANN, A. (Hrsg.). Kommunikative Sozialforschung: Alltagswissen und Alltagshandeln, Gemeindemachtforschung, Polizei, politische Erwachsenenbildung. Munique: Fink, 1976, pp. 159-260.

SILVA, V. Z. Espaços coletivos de trabalho: entre a produção e a reprodução. Tese (Doutorado em Arquitetura e Urbanismo). Universidade Federal de Minas Gerais (UFMG), Belo Horizonte, 2014.

SINGER, P. Economia política da urbanização. São Paulo: Contexto, 2002.

SOUZA, M. L. Conceitos fundamentais da pesquisa socioespacial. Rio de Janeiro: Bertrand Brasil, 2013.

SPRADLEY, J. P. The Ethnographic Interview. Fort Worth: Hartcourt Brace Jovanovich, 1979.

THIOLLENT, M. J. M. et al. Crítica metodológica, investigação social e enquete operária. São Paulo: Polis, 1980. 


\section{Silke Kapp}

Arquiteta-urbanista, mestre e doutora em Filosofia. É professora da Escola de Arquitetura, Departamento de Projetos, da Universidade Federal de Minas Gerais (UFMG) e coordenadora do Grupo de Pesquisa MOM (Morar de Outras Maneiras) na cidade de Belo Horizonte, Minas Gerais, Brasil.

Email: kapp.silke@gmail.com

ORCID: 0000-0002-3386-4927

Submissão: 4 de abril de 2019 .

Aprovação: 3 de outubro de 2019.

Como citar: KAPP, S. Entrevistas na pesquisa sócio-espacial. Revista brasileira de estudos urbanos e regionais. v.22, E202006, 2020. DOI 10.22296/2317-1529.rbeur.202006

Artigo licenciado sob Licença Creative Commons CC BY-NC 4.o.

https://creativecommons.org/licenses/by-nc/4.o/deed.pt_BR 